\title{
Firm Investment and Exporting: Evidence from China's Value-Added Tax Reform*
}

\author{
Qing Liu, University of International Business and Economics, China \\ Yi Lu, National University of Singapore, Singapore
}

July 2015

\begin{abstract}
This paper contributes to the literature by identifying the causal effect of firm investment on exporting behavior. The identification hinges on regional variations in the 2004 value-added tax pilot reform in China, which generated positive investment shocks. The instrumental variable estimation results show that firm investment significantly and substantially increases the likelihood of exporting, and this effect is largely due to the positive effect of firm investment on firm productivity. Finally, the paper documents some heterogeneity of the effect across industries with different degrees of competition and financial constraints.
\end{abstract}

Keywords: Value-added Tax Reform; Fixed Investment; Exporting Behavior; Difference-in-Differences

JEL Codes: C23, F10, G31

${ }^{*}$ We are grateful to Nina Pavcnik (co-editor) and two anonymous referees for very helpful comments and suggestions which substantially improve the paper. All remaining errors are our own. 


\section{Introduction}

"The key unanswered question is how firms obtain the characteristics that allow them to easily enter the export market." Bernard and Jensen (2004)

A robust finding from recent firm-level analyses is that exporters are more productive than non-exporters (for a review of empirical evidence, see Bernard, Jensen, Redding, and Schott, 2012). The leading explanation is that firms with better characteristics (such as productivity) self-select into export markets (for a review of firm heterogeneity theories, see Redding, 2011). However, a question that continues to intrigue researchers is how firms obtain superior characteristics to facilitate their entrance into the export market, as exemplified in the above quotation.

Recent literature has emphasized the importance of firm investment in technology upgrading for successful exporting (see, for example, Damijan, Kostevc, and Polanec, 2008; Cassiman, Golovko, and Martinez-Roz, 2010; Iacovone and Javorcik, 2012). However, there is an inherent empirical challenge to establish the causality from firm investment to exporting; that is, investment and exporting decisions are jointly determined. For example, Atkeson and Burstein (2010), Lileeva and Trefler (2010), Aw, Roberts, and Xu (2011), and Bustos (2011) all model the simultaneous selection of investment in technology upgrading and exporting. Meanwhile, another complication in the identification is that there could be reverse causality from exporting to investment. For example, Criscuolo, Haskel and Slaughter (2010) find that among several thousand U.K. enterprises across all industries in 1994-2000, those engaging globally spend more resources on innovation.

This paper contributes to the literature by using a quasi-natural experiment to identify the causal effect of firm investment on firm exporting. In 2004, China started to reform its value-added tax (VAT) system in six broadly defined industries in the three northeastern provinces. ${ }^{1}$ Under the new taxation system, the purchase of fixed assets can be deducted from the tax base, which substantially lowers the cost of fixed assets (e.g., by 13 to 17 percent) and hence generates substantial tax incentives for firms to invest. Previous studies (e.g., Chen, He, and Zhang, 2011) have shown that the VAT reform indeed increased firm investment.

Our empirical analysis uses regional variations generated by the 2004 VAT reform, that is, the reform was first piloted in only 3 of 31 provinces, as an instrument for firm investment. Meanwhile, to further improve our identification, we adopt a plausibly exogenous instruments framework developed by Conley, Hansen, and Rossi (2012), which relaxes the strict exogeneity condition of the instrumental variable. We find that firm

\footnotetext{
${ }^{1}$ Chandra and Long (2013) use another feature of the 2004 VAT reform (i.e., the sharing rule between local and central government in providing export rebates) to identify the effect of the export tax rebate on exporting performance.
} 
investment has a positive and statistically significant effect on the probability of exporting. Specifically, the average exporting propensity of northeastern firms increases by 2.39 percent due to the increase in fixed investment after the reform, which is large relative to the average exporting propensity of 32.94 percent for the whole sample. These findings are robust to a battery of sensitivity checks, including using a different standard errors estimation, checking a multi-industry issue, using a surviving firms sample, using an alternative measurement of investment incentives, and using different subsamples.

To shed light on the underlying mechanisms through which firm investment increases the probability of exporting, we first show that firm investment significantly improves firm productivity, which in turn significantly increases the probability of exporting. We also find that the effect of firm investment on the probability of exporting is larger in industries facing larger financial constraints, implying that firms are bounded on the supply side of credit and the VAT pilot reform largely increased firm investment by reducing credit constraints. We further find that the effect of firm investment is larger in more competitive industries, suggesting that firms in less competitive industries may partially pass the effect of the VAT pilot reform to their consumers, resulting in a smaller effect.

The remainder of the paper is organized as follows. Section 2 lays out the estimation framework, including a description of the institutional background of the VAT reform in China, a brief discussion of the conceptual framework, data and variables, and the identification strategy. Empirical findings, including main results, robustness checks and mechanisms, are presented in Section 3. The paper concludes with Section 4.

\section{Empirical Strategy}

\subsection{Value-Added Tax Reform in China}

The VAT is a widely-used type of tax. For example, more than 130 countries (including both developed and developing countries) have adopted VAT and raised about 20 percent or more of their tax revenues from it. The advantage of the VAT lies in its simplicity and efficiency due to the low administration cost and less economic distortion. ${ }^{2}$ A commonly used type of VAT is the consumption type, that is, the tax is levied based on the difference between firms' total sales of their products and their purchases of all inputs (including fixed assets).

China introduced the VAT nationwide in its 1994 fundamental tax reform. The standard tax rate was 17 percent, while for some goods, such as agricultural products, the

\footnotetext{
${ }^{2}$ Metcalf (1995) discusses the basic concept and administration issues of the VAT. Using data from OECD countries, Dougan and Zhang (2010) show that the VAT is neutral to private saving, whereas income taxation has a substantial negative impact on private saving. See also Auerbach (2009) and references therein.
} 
tax rate was 13 percent. Since its introduction, the VAT has become the major source of tax revenue for the Chinese government. For example, VAT revenue in 2007 accounted for about 31 percent of total tax revenue. ${ }^{3}$

However, before the reform in 2004, China's VAT was different from the standard consumption type VAT in other countries, as firms' investment in fixed assets was not deductible from the tax base. Therefore, fixed assets were taxed twice: once directly when firms purchased the assets and once indirectly when consumers bought goods produced with these assets. Such double taxation raised the cost of fixed assets and discouraged firms' investment in fixed assets. The adoption of the so-called production type VAT was an outcome of China's economic conditions at the time when the VAT was introduced. In 1994, China's economy was experiencing overheating and the central government faced stringent budget constraints. As a result, the production type VAT was conceived as a way for the central government to raise tax revenue and restrain investment in fixed assets.

A decade after the 1994 reform, the overall economic environment in China had changed significantly. On the one hand, through a series of fiscal centralization policies, the fiscal position of the central government improved substantially: from 1995 to 2004, budgetary revenue increased from 10.8 percent to around 20 percent of GDP. On the other hand, the macroeconomic austerity policy since mid-1993 effectively controlled the crisis of overheating and hyper-inflation. The new question faced by the Chinese reformists was how to deepen the economic reform, such as by providing a level playing field and improving the competitiveness of firms.

As a way to stimulate investment and promote an equitable market environment, the central government started to consider reforming its VAT system. On September 12, 2004, the Chinese Ministry of Finance and the State Administration of Taxation officially announced that China would reform its VAT system in six broadly defined industries (i.e., equipment manufacturing, petroleum and chemical manufacturing, metallurgy, ship building, automobile manufacturing, and agricultural product processing industries) in three northeastern (NE) provinces (i.e., Liaoning, Jilin, and Heilongjiang). ${ }^{4}$ The new VAT regime was applicable to transactions from July 1, 2004 onward. The crux of this VAT reform was to change the previous production type VAT to the standard consumption type VAT. Under the new VAT system, the purchase of fixed assets could be deducted from the tax base, which would substantially lower the cost of fixed assets (e.g., by 13 to 17 percent). Three years later, the reform was expanded to include another 26 cities in six central provinces and mining and electricity industries. Finally, the new VAT policy became applicable to all provinces and all industries in January 2009.

\footnotetext{
${ }^{3}$ See http://finance.people.com.cn/GB/1045/8324441.html (accessed August 21, 2012).

${ }^{4}$ See "Decisions on the Expansion of Deduction of Value-Added Taxation in the Northeastern Provinces" (http://www.chinatax.gov.cn/n8136506/n8136563/n8193451/n8193556/n8194481/8249242.html).
} 
Table 1 lists eligible as well as ineligible manufacturing industries in the VAT pilot reform in 2004. The majority of manufacturing industries are eligible and the inclusiveness in classification makes it particularly difficult for firms to switch industries to take advantage of the tax incentive, ensuring that the same firm was either eligible or ineligible before and after the pilot reform. Meanwhile, as shown by Chen, He and Zhang (2011), the distribution of eligible and ineligible firms is balanced between NE and non-NE cities and before and after the pilot reform, which makes concerns about the industry selection problem less severe.

\subsection{Conceptual Framework}

To illustrate how the VAT reform affects exporting behavior (through investment in technology upgrading), we briefly discuss a conceptual framework that extends the heterogeneous firm framework developed by Melitz (2003) to a two-period one. Specifically, in the first period, upon paying a fixed cost of entry, firms draw their productivity levels, and then decide whether to exit the market immediately or start production. If firms choose to produce, they need to pay a fixed cost of production, and at the same time have two additional options - export to the foreign market (with a fixed cost) and invest in technology upgrading (with a fixed cost). Investment in technology upgrading will increase firm productivity to a given level (which is assumed to be higher than the cutoff productivity level of exporting). ${ }^{5}$ In the second period, if a firm invests in technology upgrading in the first period, it will have a new productivity level in the second period and the firm reconsiders its production and exporting behavior based on the new productivity. For firms who do not invest in technology upgrading, their production and exporting behavior in the second period will be the same as in the first period.

The VAT reform in China changes the cost of investment in technology upgrading, as shown in the previous section, in northeastern cities where such investment was absent in firms for years. To fit into this institutional context, we assume that (1) before the reform, the VAT is large enough to deter firms from investing in technology upgrading; and (2) after the reform, the abolishment of the VAT on investment makes the investment in technology upgrading affordable. Given mild assumptions about fixed costs of exporting and investment, it can be shown that among non-exporters, in the post-VAT reform period, less productive firms invest in technology upgrading and start exporting; while more productive firms maintain status quo. Among exporters, in the post-VAT reform period, all continue to export and do not invest in technology upgrading. As a result, on average the ratio of exporters in the population after the VAT reform increases.

These results are intuitive. When advanced technology is available for a reasonable fixed cost, firms' investment behavior will be determined by the magnitude of their gains

\footnotetext{
${ }^{5}$ See, for example, Lileeva and Trefler (2010) for the similar assumption.
} 
from technology upgrading. For high productivity firms, the gains will be small and thus they will not invest. But for low productivity firms, the gains will be large and they have higher incentives to invest. More generally, the lower is the initial productivity of the firm, the larger will be the gains from investment and, therefore, the more likely the firm will invest and export.

\subsection{Data}

The main data set used in this study comes from the Annual Survey of Industrial Firms (ASIF), conducted by the National Bureau of Statistics of China from 1998 to 2007. This is the most comprehensive firm-level data set in China, as it covers all state-owned enterprises and all non-state-owned enterprises with annual sales above five million Renminbi (around US\$650,000). The number of firms varies from more than 140,000 in the late 1990s to more than 243,000 in 2007 . The data set spans all 31 provinces or provinceequivalent municipalities, and all manufacturing industries, which ensures its invaluable national representativeness.

The data set provides detailed firm information, including industry affiliation, location, and all operation and performance items from the accounting statements, such as exports, book value and net value of fixed assets, employment and wage rate. We depreciate all pecuniary variables with 2-digit price deflators constructed by Brandt, Van Biesebroeck, and Zhang (2012). However, one drawback of this data set is that it does not directly provide information on fixed investment. To obtain data on fixed investment, we follow Song and $\mathrm{Wu}$ (2012) in using book values of fixed assets (reported in the ASIF data set) and assuming a constant depreciation rate of 5 percent. Specifically, investment by firm $f$ in year $t, I N V_{f, t}$, is constructed with the equation

$$
K_{f, t+1}=(1-\delta) K_{f, t}+I N V_{f, t}
$$

where $\delta=0.05$ is the constant depreciation rate; $K_{f, t}=(1-\delta) K_{f, t-1}+\left(B K_{f, t}-B K_{f, t-1}\right) / P_{r t}$ is the capital stock for firm $f$ in year $t ; B K_{f, t}$ is the book value of capital stock for firm $f$ in year $t$; and $P_{r t}$ is the provincial fixed investment price index in year $t$ (from various years of the Chinese Statistical Yearbook compiled by the National Bureau of Statistics of China). For firms established after 1998, the initial book value of capital stock $\left(B K_{f, t}\right)$ is taken directly from the data set. For firms founded before 1998, say 1985, we assume the same capital growth rate for the concerned firm during 1985-1998 as that during 1998-2004 to predict the initial book value at the time of its establishment. Specifically, $B K_{f, t_{0}}=B K_{f, t_{1}} /\left(1+g_{f}\right)^{t_{1}-t_{0}}$, where $B K_{f, t_{0}}$ is the projected initial book value of capital stock for firm $f$ born in year $t_{0} ; B K_{f, t_{1}}$ is the book value of capital stock for firm $f$ that first appeared in the data set in year $t_{1}$; and $g_{f}$ is the geometric average capital stock growth rate of firm $f$ for the periods observed in the data set since year $t_{1}$. 
Table 2a provides summary statistics and definitions of our key variables, respectively, for the whole sample and for two subsamples - NE cities (the location of the VAT pilot reform in 2004) and non-NE cities. The majority of firms are non-exporters; only 32.9 percent of firm-year observations belong to exporters, which is consistent with the general picture in the literature (e.g., Bernard and Jensen, 1999; Mayer and Ottaviano, 2008). Meanwhile, firms in non-NE cities are more engaged in international trade than their counterparts in NE cities. That is, non-NE cities have higher percentages of exporters, higher export intensity, higher total export values, and larger coverage of export markets. One possible explanation for this pattern is that the opening of China in the late 1970s started in the southern, coastal regions, such as Guangdong and Fujian provinces.

Table $2 \mathrm{~b}$ further shows the comparison of exporter shares in NE and non-NE cities for each of the 24 eligible 2-digit industries. In the majority of industries, non-NE cities have higher exporting propensity than NE cities, but the latter have higher percentages of exporters in industries like Smelting and pressing of ferrous metals, Petroleum processing, and Agricultural and by-product. Firms located in NE cities tended to invest less than those in other places, reflecting the motivation of the central government to select $\mathrm{NE}$ cities as pilot reform sites.

\subsection{Identification Framework}

As elaborated in Meltiz (2003), the exporting decision hinges on whether the net export revenue is higher than the fixed cost of exporting. Specifically, the exporting decision by firm $f$ located in city $c$ in industry $i$ in year $t$ is written as

$$
E X P_{f, i, c, t}=\left\{\begin{array}{cc}
1 & \text { if } \hat{R}_{f, i, c, t}>F \cdot\left(1-E X P_{f, i, c, t-1}\right) \\
0 & \text { otherwise }
\end{array},\right.
$$

where $E X P_{f, i, c, t}$ is the exporting status; $\hat{R}_{f, i, c, t}$ is the expected net export revenue; and $F$ represents the fixed cost for new exporters.

Empirically, we proxy $\hat{R}_{f, i, c, t}$ using the information available at the beginning of period t. Specifically, following Bernard and Jensen (1999, 2004), we use firm size and wage rate, both measured in logarithm and at the end of period $t-1$. We include firm investment incurred during period $t-1$, which in turn affects firm productivity and $\hat{R}_{f, i, c, t}$ in period $t$. Further including industry and city time-invariant characteristics and common time effects, we have

$$
\hat{R}_{f, i, c, t}=\beta I N V_{f, i, c, t-1}+\mathbf{X}_{f, i, c, t-1}^{\prime} \boldsymbol{\eta}+\lambda_{i}+\lambda_{c}+\lambda_{t}
$$

where $I N V_{f, i, c, t-1}$ is firm investment, our regressor of interest; $\mathbf{X}_{f, i, c, t-1}$ is a vector of firm characteristics including the logarithm of firm size, and the logarithm of wage rate; $\lambda_{i}$ is 
the 2-digit industry fixed effect, capturing all time-invariant industrial characteristics; ${ }^{6}$ $\lambda_{c}$ is the city fixed effect, capturing all time-invariant city characteristics including geographic features; and $\lambda_{t}$ is the time fixed effect, capturing all shocks common to all firms in the same year such as macroeconomic shocks.

Linearizing equation (2) and including $E X P_{f, i, c, t-1}$ in $\mathbf{X}_{f, i, c, t-1}$, we have the following estimation equation

$$
E X P_{f, i, c, t}=\beta I N V_{f, i, c, t-1}+\mathbf{X}_{f, i, c, t-1}^{\prime} \boldsymbol{\eta}+\lambda_{i}+\lambda_{c}+\lambda_{t}+\varepsilon_{f, i, c, t} .
$$

We use heteroskedasticity-robust standard errors $\varepsilon_{f, i, c, t}$ clustered at the city level to deal with potential heteroskedasticity and serial correlation problems (see Bertrand, Duflo and Mullainathan, 2004).

The crucial assumption for identifying the investment effect on exporting is that conditional on all controls, firm investment is uncorrelated with the error term. However, it is reasonable to doubt the satisfaction of this identifying assumption. For example, an aggressive CEO could be keen on investing and selling to foreign markets.

To improve the identification, we explore time and regional variations in the reduction in the VAT generated by the VAT pilot reform, which has been shown to generate substantial incentives for firms to invest (e.g., Chen, He, and Zhang, 2011). Specifically, we focus on the sample of eligible industries in the 2004 VAT pilot reform and use the policy reform to construct an instrument for firm investment. The first stage of the instrumental variable estimation is

$$
I N V_{f, i, c, t}=\alpha V A T_{c, t}+\mathbf{X}_{f, i, c, t}^{\prime} \boldsymbol{\lambda}+\lambda_{i}+\lambda_{c}+\lambda_{t}+v_{f, i, c, t}
$$

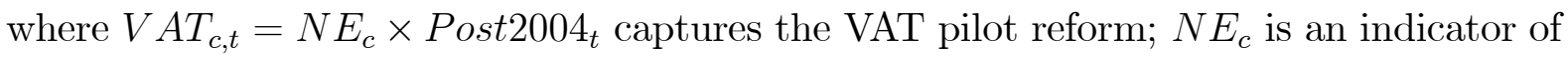
northeastern cities; and Post2004 $t$ is a post-reform indicator, taking a value of 0 for 19982003, 0.5 for 2004, and 1 for 2005-2007. $v_{f, i, c, t}$ is the heteroskedasticity-robust standard error clustered at the city level.

The validity of the instrumental variable estimation hinges on two conditions, that is, the relevance condition (i.e., our instrumental variable is significantly correlated with our regressor of interest and this correlation is strong) and the exclusion restriction (i.e., our instrumental variable does not affect our outcome variable through channels other than the regressor of interest). While the relevance condition can be confirmed by the significance of $\alpha$ in equation (4), the exclusion restriction requires further discussion.

There are two potential threats to the exclusion restriction of our instrument. The first one is that the pilot sites in the 2004 VAT pilot reform (i.e., three NE provinces) were not randomly selected, which implies that pilot sites and other places could be fun-

\footnotetext{
${ }^{6}$ Results are robust to the use of 3-digit and 4-digit industry fixed effects (see columns 1-2 of Appendix Table 1).
} 
damentally different and our instrument may affect the probability of exporting directly through these fundamentals. To address this concern, we turn to the recent imperfect instrumental variable literature, which relaxes the exogeneity assumption of instrumental variables. Specifically, we adopt the plausibly exogenous instruments framework developed by Conley, Hansen, and Rossi (2012). Consider a generalization of our instrumental variable equation

$$
E X P_{f, i, c, t}=\beta I N V_{f, i, c, t-1}+\gamma V A T_{c, t-1}+\mathbf{X}_{f, i, c, t-1}^{\prime} \boldsymbol{\eta}+\lambda_{i}+\lambda_{c}+\lambda_{t}+\varepsilon_{f, i, c, t},
$$

where $\gamma$ captures all the effects of our instrument $V A T_{c, t-1}$ on our outcome variable $E X P_{f, i, c, t}$ through channels other than our regressor of interest $I N V_{f, i, c, t-1}$. Given $\gamma$, our instrument can identify the true value of $\beta$ in a modified equation, i.e.,

$$
\widetilde{\operatorname{EXP}}_{f, i, c, t}=\beta I N V_{f, i, c, t-1}+\mathbf{X}_{f, i, c, t-1}^{\prime} \boldsymbol{\eta}+\lambda_{i}+\lambda_{c}+\lambda_{t}+\varepsilon_{f, i, c, t},
$$

where $\widetilde{\operatorname{EXP}}_{f, i, c, t} \equiv E X P_{f, i, c, t}-\gamma V A T_{c, t-1}$.

A practical issue is how to estimate $\gamma$. Following the practice by Nunn and Wantchekon (2011), we exploit the institutional details of the 2004 VAT pilot reform, that is, there existed several reform-ineligible industries in pilot and non-pilot sites. As the VAT pilot reform did not affect these ineligible industries (and hence our instrument $V A T_{c, t-1}$ does not affect our regressor of interest $\left.I N V_{f, i, c, t-1}\right)$, a regression of $E X P_{f, i, c, t}$ on $V A T_{c, t-1}$ along with the same set of controls (i.e., $\left.\mathbf{X}_{f, i, c, t-1}, \lambda_{i}, \lambda_{c}, \lambda_{t}\right)$ in the sample of reformineligible industries captures all the effects of $V A T_{c, t-1}$ on $E X P_{f, i, c, t}$ through channels other than $I N V_{f, i, c, t-1}$; in other words, it provides an estimation of $\gamma$. With the estimated $\hat{\gamma}$, we can then calculate the outcome variable $\widetilde{\operatorname{EXP}}_{f, i, c, t}=E X P_{f, i, c, t}-\hat{\gamma} V A T_{c, t-1}$ in equation (5) and identify $\beta$ using $V A T_{c, t-1}$ as the valid instrument.

The second potential bias is that if there were other reforms happening at the same time, our instrument may capture the effects of these other reforms, which may in turn affect our outcome variable through channels other than firm investment. One example is the removal of the Multifiber Arrangement (MFA) that came into effect on January 1, 2005 and substantially increased Chinese exports in the textile and clothing industries (see Khandelwal, Schott, and Wei, 2013, for a recent study on this event). As NE cities (the location of the 2004 VAT pilot reform) hosted mostly heavy industries, our instrument may correlate with the MFA reform, which directly affected the exporting behavior of firms. To address this concern, we add, as a control, an interaction between an indicator of MFA-affected industries (i.e., $M F A_{i}=1$ for Textiles industry and Garments industry; and 0 otherwise) and a post-2005 time indicator (i.e., Post2005 $5_{t}=1$ for 2005-2007 and 0 otherwise), i.e., $M F A_{i} \times$ Post $2005_{t}$. 


\section{Empirical Results}

\subsection{Main Results}

The instrumental variable estimation results are reported in Table 3, with panel A for the second stage results and panel B for the first stage results. The first stage estimation results demonstrate a positive and statistically significant effect of the VAT pilot reform on firm investment. These results are consistent with the findings by Chen, He, and Zhang (2011), and confirm the relevance of our instrumental variable.

In column 1 of Table 3, we use the raw data on exporting status and find a positive and statistically significant effect of firm investment on the likelihood of firm exporting, a result consistent with the literature (e.g., Aw, Roberts and Xu, 2011; Bustos, 2011). ${ }^{7}$ Meanwhile, the magnitude is found to be economically significant. Given the fact that average fixed investment of NE firms increases by 17.91 percent after the reform, our estimation result implies that the exporting propensity of northeastern firms increases by 2.39 percent because of fixed investment, which is large relative to the average exporting propensity of 32.94 percent in the whole sample. That is, the probability of exporting is increased by the VAT pilot reform by 7.26 percent relative to the sample mean.

In column 2 of Table 3, we address the potentially nonrandom selection of the VAT pilot reform sites and hence the endogeneity of our instrument by using the plausibly exogenous instruments framework proposed in equation (5). We consistently find a positive and statistically significant effect of firm investment on exporting probability, and the magnitude almost does not change.

The plausibly exogenous instruments framework requires that our instrument affects the likelihood of exporting in the VAT pilot reform eligible industries and the VAT pilot reform ineligible industries similarly in the absence of firm investment (i.e., $\gamma^{e}=\gamma^{i n e}$ ). In other words, our estimate in column 2 of Table 3 would be biased if there were cityindustry specific shocks, for example, shocks affecting the VAT pilot reform sites and the VAT pilot reform eligible industries differentially from other locations and other industries. We have addressed one possible city-industry specific shock, that is, the removal of the MFA on January 1, 2005, by including an additional control $M F A_{i} \times$ Post2005 $t$ in all our regressions.

Another possible city-industry specific shock is that NE regions largely hosted heavy industries, which were mainly controlled by state-owned-enterprises (SOEs). ${ }^{8}$ During

\footnotetext{
${ }^{7}$ We also experiment with three alternative measures of exporting behavior, i.e., total export revenue, export intensity, and the number of export markets. As shown in columns 3-5 of Appendix Table 1, we find that firm investment (after being instrumented) significantly increases its total export values, but not export intensity or the number of export markets. While new exporters increase their export intensity and the number of export markets, the overall insignificant effects on export intensity and the number of export markets suggest the countervailing behavior of existing exporters and the dominance of the existing exporters in total exports.

${ }^{8}$ It is also possible that after the VAT pilot reform, the government increased credit supply to eligible
} 
the sample period, China went through a series of privatization and restructuring of SOEs, which may have generated a city-industry specific shock. To control for this possible estimation bias, we construct two alternative measures - both at the firm levelto capture the effect of firm ownership. Specifically, in column 3, we first include the share of a firm's equity owned by the state sector (denoted by State Share), and find that the results are robust to this additional control. Second, in column 4, we classify firms into different ownership types - specifically, SOEs, Chinese private firms, firms invested by multinationals from Hong Kong, Macau, and Taiwan (HMT), and firm invested by multinationals from other foreign countries - based on their registration types reported in the data. We include three firm-level ownership indicators - SOE, Foreign-Invested Firms, HMT-Invested Firms - as additional controls with the omitted default firm ownership type being Chinese private firms, and find robust results. The combination of these two exercises suggests that our findings are not driven by firms with different ownership types.

The identifying assumption of our plausibly exogenous instruments framework may also not hold if the government actively selected which industries to be eligible for the VAT pilot reform and which not. Specifically, our estimates would be systematically biased upward (downward) if the VAT pilot reform had a larger (smaller) direct effect on exporting in eligible industries than ineligible industries. ${ }^{9}$ As a further check, we conduct a placebo test, that is, we randomly generate a year of the VAT pilot reform between 2000 and 2006 (as we need to include two years of lag and at least one post-reform period), and randomly select 38 out of 414 cities to be the reform sites (as the 2004 VAT pilot reform took place in 38 cities). ${ }^{10}$ Based on these random draws, we then construct a false VAT pilot reform variable $\left(\widetilde{V A T}_{c, t}\right)$, and use $\widetilde{V A T}_{c, t}$ as the regressor of interest in a reduced-form regression similar to equation $(5),{ }^{11}$ i.e.,

$$
\widetilde{E X P}_{f, i, c, t}=\delta \widetilde{V A T}_{c, t}+\mathbf{X}_{f, i, c, t-1}^{\prime} \boldsymbol{\eta}+\lambda_{i}+\lambda_{c}+\lambda_{t}+\varepsilon_{f, i, c, t}
$$

industries in treatment provinces, which may in turn affect firm exporting behavior. While the lack of credit supply data at the city-industry level prevents us from directly checking this possibility, we perform an indirect test. Specifically, we use a firm's total debts to partially capture the degree of credit supply, and then control for it in the analysis. As shown in column 6 of Appendix Table 1, our results about the effect of firm investment on exporting remain robust to this additional control, suggesting that the change in credit supply after the VAT pilot reform may not be the main driver of our findings.

${ }^{9}$ Equation (5) is essentially estimated as

$$
\begin{aligned}
\widetilde{E X P}_{f, i, c, t} & =E X P_{f, i, c, t}-\gamma^{i n e} V A T_{c, t-1} \\
& =\beta I N V_{f, i, c, t-1}+\mathbf{X}_{f, i, c, t-1}^{\prime} \boldsymbol{\eta}+\lambda_{i}+\lambda_{c}+\lambda_{t}+\tilde{\varepsilon}_{f, i, c, t},
\end{aligned}
$$

where $\tilde{\varepsilon}_{f, i, c, t}=\left(\gamma^{e}-\gamma^{i n e}\right) V A T_{c, t-1}+\varepsilon_{f, i, c, t}$. Hence, when $\gamma^{e}>\gamma^{i n e}, \hat{\beta}>\beta$; and when $\gamma^{e}<\gamma^{i n e}$, $\hat{\beta}<\beta$.

${ }^{10}$ We thank an anonymous referee for this suggestion.

${ }^{11}$ It is not proper to perform an instrumental variable estimation using equation (5), as $\widetilde{V A T}_{c, t}$ does not have explanatory power in the first stage. 
We repeat this exercise 1,000 times. If equation (5) is correctly specified, we shall find that most of these 1,000 coefficients $(\hat{\delta})$ have values close to zero and they are overall not systematically different from zero.

In Figure 1, we plot the density distribution of the 1,000 estimates from the random draw of the VAT pilot reform year and sites. We find that the distribution of these estimates is centered around zero (i.e., the mean value is 0.000075 ), and our estimate using the true VAT pilot reform year and sites (i.e., 0.0225) is beyond the $95 \%$ quantile of these 1,000 placebo estimates (i.e., the $95 \%$ quantile is 0.0156 ). These results further boost our confidence that our findings are not severely biased by misspecification of the estimation equation.

In Appendix Table 2, we further test differential effects of the VAT pilot reform on firm investment and firm exporting for initial non-exporters with different productivity levels (i.e., low and high) and initial exporters. Specifically, initial exporters are firms that ever exported before the VAT pilot reform in 2004, and firms that did not export before the VAT pilot reform are defined as initial non-exporters. We further divide initial nonexporters into two groups based on whether their pre-reform average productivity levels are above or below the median productivity level of the whole initial non-exporters group in each 4-digit industry. Initial non-exporters with low productivity levels (but not initial non-exporters with high productivity levels or initial exporters) increased their investment in response to the VAT pilot reform. Meanwhile, the VAT pilot reform increased the probability of exporting for all initial non-exporters but not for initial exporters. One possible explanation for these heterogeneous effects across firms is that what we have identified here is the city average effect of firm investment on firm exporting. This average effect includes not only the direct effect of firm investment on its own exporting, but also indirect effects through interactions of firms in the same city. For example, the increase in firm investment may improve infrastructure quality in the city, which generates positive spillovers to other firms in the same locality and in turn affects their exporting behavior. Also there may exist a general equilibrium effect, e.g., new exporters may steal the market from existing exporters.

\subsection{Robustness Checks}

We provide some further robustness checks on the aforementioned estimation results in this subsection. To save space, we focus on the estimation specification in column 3 of Table 3, and only report the second-stage results of the instrumental variable estimations (the first-stage results are available on request).

Clustered Standard Errors at the Province Level. Although the 2004 VAT pilot reform was implemented at the province level, we calculate clustered standard errors at the city level in our previous regressions mainly for two reasons. First, Chinese provinces 
are large in geographic scale and there are substantial variations across cities within a province. Second, local city governments had much discretion in enforcing the reform in their localities, generating city variations in the implementation of the pilot reform. Nonetheless, as a robustness check, we calculate the standard errors clustered at the province level in column 1 of Table 4 . We continue to find a significant effect of firm investment on the probability of exporting.

Single- vs. Multi-industry Firms Sample. Firms may produce goods and conduct investment in multiple industries, but our data only record one industry affiliation for each firm. Without detailed information about firm investment by industry, we may encounter estimation biases due to cross-industry spillovers or measurement errors, especially when firms are active in both reform-eligible and reform-ineligible industries. To check whether and how our estimates are biased due to this multiple-industry issue, we obtain a product-level data set from the National Bureau of Statistics of China for 2000-2005, which contains information on each product (defined at the 5-digit product level) produced by the firm. As the product-level data and the ASIF data use the same firm identity, we can easily match the data, and then determine whether a firm produces goods in single or multiple 3 -digit industries.

With this information in hand, ideally, we can split firms in our baseline sample into two groups - that is, firms active only in eligible industries, and firms active in both eligible and ineligible industries - and test whether the coefficients are different in these two subsample regressions. ${ }^{12}$ However, there are very few firms (i.e., less than $1 \%$ ) producing in both eligible and ineligible industries, which precludes the implementation of this robustness check. ${ }^{13}$

Instead, we divide firms into two groups, based on whether they are active in single or multiple 3-digit industries. Two subsample regression results are reported in columns 2 and 3 of Table 4, respectively. Consistent with our baseline findings, both estimates are significantly positive. However, the estimated magnitude in the single-industry firms sample (0.2098) is larger than the average effect in the whole sample (0.1730), which is in turn larger than that in the multi-industry firms sample (0.1270). One possible interpretation of these results is that there exist some negative cross-industry spillovers in investment. Another possible interpretation is that there are potential measurement errors with the status of the VAT-pilot-reform eligibility; in particular, it is difficult for multi-industry firms to identify what share of their production was affected by the VAT pilot reform. Measurement errors in our regressor of interest may then bias the coefficient of interest in the multi-industry firms sample downward.

Surviving Firms Sample. With our regressor of interest measured at the city level,

\footnotetext{
${ }^{12}$ Note that the third group of firms - firms are active only in ineligible industries - are not in our baseline regression sample.

${ }^{13}$ As shown in column 7 of Appendix Table 1, our results remain robust to the exclusion of firms producing in both VAT-pilot-reform eligible and ineligible industries.
} 
we are essentially estimating the city average effect of investment on the probability of exporting, that is, whether firms on average become more exporting-oriented in cities with the VAT pilot reform than in cities without the reform. However, the firm composition of cities might change over time. For example, some firms left our sample (exiters), some entered our sample (new entries), and some survived the reform (surviving firms). If new entries and/or exiters had different degrees of investment and exporting across reform cities and other regions, our aforementioned estimation results may just capture the selection effect, instead of the true effect of investment on the probability of exporting. In studying the effect of trade liberalization on firm productivity, Pavcnik (2002) first incorporates such firm exits in the estimation of the production function to more accurately calculate firm productivity, and then finds that exiters have lower productivity levels than surviving firms.

To check whether our estimates are driven by entries and exits, we focus on a sample of surviving firms (i.e., those existed both before and after the VAT pilot reform in 2004). Regression results are reported in column 4 of Table 4 . We continue to find a significant effect of investment, and the magnitude becomes even larger, implying that the selection from entries and exits does not drive our findings and only biases our estimate downward.

Capital-Labor Ratio. Given that our data do not record firm investment information, the investment variable used in our analysis is calculated based on equation (1), with some underlying assumptions for the capital growth rate. As the VAT pilot reform reduced the marginal cost of capital relative to that of labor, firms may respond optimally by shifting their production function toward capital, resulting in an increase in the capital-labor ratio. Given that the capital and labor information is well recorded in the data, we use the capital-labor ratio to provide additional evidence of an increase in investment after the VAT pilot reform and look at the effect of investment on firm exporting. In the unreported first-stage results of the instrumental variable estimation, we find that the VAT pilot reform in 2004 significantly increased firms' capital-labor ratio, i.e., the coefficient is 0.1631 with a significance level of $1 \%$. As shown in column 5 of Table 4, after being instrumented, the capital-labor ratio is found to have a positive and statistically significant effect on the probability of exporting, consistent with our findings using the measure of firm investment.

SOEs vs. Non-SOEs. Cai and Harrison (2011) show that the VAT pilot reform has different investment effects for SOEs and non-SOEs. To check whether our findings regarding the effect of firm investment on exporting differ across SOEs and non-SOEs, we conduct two separate regressions for these two groups. In the unreported first-stage results of the instrumental variable estimation, we find that the investment effect of the VAT pilot reform is larger for SOEs (with an estimated coefficient of 0.1873 and standard error of 0.0833) than that for non-SOEs (with an estimated coefficient of 0.0848 and standard error of 0.0750), consistent with the findings in Cai and Harrison (2011). 
Columns 6 and 7 of Table 4 show that the effect of firm investment on the probability of exporting is positive and statistically significant for non-SOEs, but insignificant and small in magnitude for SOEs. These results for SOEs and non-SOEs are puzzling - that is, the effect of VAT pilot reform holds for non-SOEs but not for SOEs, despite the fact that the non-SOEs do not increase investment in response to the reform. However, we conduct this split-sample analysis mainly to compare our findings with Cai and Harrison (2011)'s, and find similar results. Meanwhile, we demonstrate in columns 3 and 4 of Table 3 that our main findings regarding the effect of firm investment on exporting remain robust to the control of SOE versus non-SOE ownership.

\subsection{Discussion}

In the previous sections, we have identified a significant and positive effect of fixed investment on the likelihood of exporting. In this subsection, we provide some further evidence to shed light on the underlying mechanisms through which firm investment may affect the likelihood of exporting.

Productivity Enhancement. One potential mechanism is that the VAT reform provides substantial tax incentives for firms to upgrade their technologies, which subsequently improves their productivity levels and hence enhances the propensity to export (see, e.g., Atkeson and Burstein, 2010; Lileeva and Trefler, 2010; Aw, Roberts, and Xu, 2011; and Bustos, 2011).

To test this productivity enhancement channel formally, we conduct two exercises. First, we regress firm productivity on firm investment using the VAT pilot reform as an instrument for the investment. For the measurement of firm productivity, we focus on total factor productivity (TFP), estimated using Levinsohn and Petrin (2003)'s method. ${ }^{14}$ Regressions using the output-labor ratio and the value-added-labor ratio as alternative measures of firm productivity produce similar results (available on request). The second stage results of the instrumental variable estimation are reported in column 1 of Table 5 . It is found that after being instrumented, firm investment has a positive and statistically significant effect on firm productivity.

Second, we regress firm exporting status on firm productivity using the VAT pilot reform as an instrument for the productivity. We find in the first stage regression that the VAT pilot reform significantly increased firm productivity levels, i.e., an estimated coefficient of 0.2282 . In the second stage regression, as shown in column 2 of Table 5 , after being instrumented, firm productivity casts a positive and statistically significant effect on the probability of exporting.

To lend further support to the argument of the productivity enhancement channel

\footnotetext{
${ }^{14}$ We estimate TFP industry-by-industry at the 2-digit industry level for each firm with value added, employment, fixed assets, and intermediate inputs. This allows each industry to have a different production function.
} 
of the effect of firm investment on firm exporting, we conduct the following back-ofthe-envelope calculation. ${ }^{15}$ Specifically, if firm investment affects firm exporting only through the productivity channel, then with the two estimated coefficients in columns 1 and 2 of Table 5, we can calculate the effect of firm investment on firm exporting as $1.6278 * 0.0941=0.1532$. We then compare this number to the overall effect of firm investment on firm exporting reported in column 3 of Table 3 (i.e., 0.1730). We find that the difference is small in magnitude (i.e., $0.1730-0.1532=0.0198$ ) and highly insignificant (i.e., the standard error clustered at the city-level has the value of 2.804). These results suggest that productivity enhancement is an important channel through which firm investment affects the probability of exporting.

To shed light on the different effects across SOEs and non-SOEs reported in columns 6 and 7 of Table 4, we investigate the productivity enhancement channel for SOEs and non-SOEs separately. As shown in columns 3 and 5 of Table 5 , firm investment has a much larger and more significant effect on firm productivity of non-SOEs than that of SOEs. Columns 4 and 6 further show that firm productivity has a much larger and more significant effect on firm exporting for non-SOEs than SOEs. These results suggest that while SOEs significantly increased firm investment after the VAT pilot reform, relative to non-SOEs, their productivity is less responsive to their investment and also their exporting behavior is less responsive to their productivity.

Financial Constraints. Firms making investment decisions consider both the demand and supply conditions, for example, the opportunity of investment and the supply of credit. The VAT pilot reform largely relaxed the constraints on the credit supply by increasing internal cash flows, implying larger effects for firms with higher financial constraints. Hence, to establish the mechanism of the investment effect on firm exporting, we consider the situation where firms face binding constraints on the supply side. Specifically, we exploit the variations in external financial dependence across sectors. Following Manova (2013) and Manova and Yu (2014), we construct the measure of external financial dependence as the share of aggregate capital expenditures not financed with internal cash flows from operations at the 4-digit industry level using the pre-reform period data. ${ }^{16} \mathrm{We}$ then divide the sample into two subsamples, i.e., firms in industries with external financial dependence above and below the median of industrial external finance dependence.

The second stage results of the instrumental variable estimations using these two subsamples are reported in columns 1 and 2 of Table 6 , respectively. It is found that industries with higher external financial dependence have a larger estimated coefficient (i.e., 0.2417) than industries with lower external financial dependence do (i.e., 0.1133). ${ }^{17}$

\footnotetext{
${ }^{15}$ We thank an anonymous referee for this suggestion.

${ }^{16}$ Results using other measures, such as the ratio of R\&D over sales and the difference between current assets and current liabilities (scaled by total assets), are similar and available on request.

${ }^{17}$ To determine whether these results are consistent with the differential results across SOEs and non-SOEs, we need to check whether the SOE share is higher in industries with higher external finan-
} 
These results suggest that the VAT pilot reform has a larger effect on industries with higher external financial dependence, and support the argument that firms are bounded by the supply of credit for investment and the VAT pilot reform increased investment by reducing this binding constraint, which in turn led to an increase in the probability of exporting.

Pass-Through. The effects of the VAT pilot reform on firm behavior, including investment and exporting decisions, depend on the interactions between producers and consumers. If firms have market power, they can pass more of the cost of VAT to their consumers, resulting in a small effect of the VAT reform on their behavior. One would therefore expect that the effects of the VAT pilot reform on firm investment and exporting to be smaller in less competitive industries than in more competitive industries. To measure the degree of industry competition, we calculate the pre-reform Herfindahl index (HHI) for each 4-digit industry; a higher value of HHI indicates a less competitive situation. ${ }^{18}$ We then divide the sample into two subsamples, firms in industries with HHI values above and below the median across industries.

The second stage results of the instrumental variable estimations using these two subsamples are reported in columns 3 and 4 of Table 6 , respectively. We find that more competitive industries have a larger estimated coefficient (i.e., 0.1844) than less competitive industries (i.e., 0.1391). ${ }^{19}$ These results support the argument that the effects of the VAT pilot reform on exporting are smaller in less competitive industries. Meanwhile, these findings are consistent with the evidence found by De Loecker, Glodberg, Khandelwal, and Pavcnik (2014) on the imperfect pass-through of cost savings from input tariff reduction to consumer prices.

\section{Conclusion}

The importance of firms' fixed investment for successful exporting has attracted much attention in the recent literature. This paper contributes to this literature by identifying the causal effect of firm investment on its exporting behavior. Specifically, we use the opportunity of a quasi-natural experiment provided by China's value-added tax reform in 2004 to deal with the potential endogeneity of fixed investment. As the pilot reform in 2004 covered only three NE provinces of China, the incentive for firm investment varied across both regions and years. We instrument firm investment with these timing and

cial dependence. Indeed, we find in Appendix Figure 1 that industries with higher external financial dependence have a larger share of SOEs (in terms of firm number, employment, sales, and output).

${ }^{18}$ Results using the number of firms are similar (available on request).

${ }^{19}$ To determine whether these results are consistent with the differential results across SOEs and nonSOEs, we need to check whether the SOE share is higher in less competitive industries. Indeed, we find in Appendix Figure 2 that SOEs are more prevalent (in terms of firm number, employment, sales, and output) in less competitive industries. 
regional variations generated by the reform to check the causal effect of fixed investment. To deal with concerns about the potential endogeneity of the reform, we use the plausibly exogenous instruments framework developed by Conley, Hansen, and Rossi (2012). We also take into account simultaneous policy changes (e.g., the removal of the MFA at the beginning of 2005), which could contaminate the results in our estimation.

We find a consistently positive and significant (statistically and economically) effect of firm investment on the probability of exporting. Specifically, the average exporting propensity of NE firms increases by 2.39 percent because of the increase in investment after the reform, which is large relative to the average exporting propensity of 32.94 percent for the whole sample.

Following the recent trade literature, we further investigate underlying mechanisms through which firm investment may affect exporting probability. Specifically, we consider firm productivity, market competition, and credit constraints, which are most relevant to our context. We find a significant productivity enhancement effect of fixed investment, which in turn promotes exporting. We also find that the effect of firm investment on exporting is larger in industries more dependent on external finance and in more competitive industries, which implies the existence of credit constraints in firm investment and of the power of firms to pass the tax reduction effects to consumers. 


\section{References}

[1] Atkeson, Andrew and Ariel Burstein. 2010. "Innovation, Firm Dynamics, and International Trade", Journal of Political Economy 118, 433-484

[2] Auerbach, Alan J. 2009. "The Choice between Consumption and Income Taxes: A Primer." In A. J. Auerbach and D. N. Shaviro, eds., Institutional Foundations of Public Finance: Economic and Legal Perspectives. Cambridge, MA: Harvard University Press.

[3] Aw, Bee Yan, Mark J. Roberts and Daniel Yi Xu. 2011. "R\&D Investment, Exporting, and Productivity Dynamics." Unpublished paper.

[4] Bernard, Andrew B. and J. Bradford Jensen. 1999. "Exceptional Exporter Performance: Cause, Effect, or Both?" Journal of International Economics 47(1), 1-25.

[5] Bernard, Andrew B. and J. Bradford Jensen. 2004. "Why Some Firms Export?", Review of Economics and Statistics 86, 561-569.

[6] Bernard, Andrew B., J. Bradford Jensen, Stephen J. Redding, and Peter K. Schott. 2012. "The Empirics of Firm Heterogeneity and International Trade", Annual Review of Economics 4, 283-313

[7] Bertrand, M., Duflo, E., Mullainathan, S. 2004. "How much should we trust differences-in-differences estimates?". Quarterly Journal of Economics 119 (1), 249275 .

[8] Brandt, Loren, Johannes Van Biesebroeck, and Yifan Zhang, 2012. "Creative Accounting or Creative Destruction? Firm-level Productivity Growth in Chinese Manufacturing", Journal of Development Economics 97(2), 339-351.

[9] Bustos, Paula. 2011. "Trade Liberalization, Exports, and Technology Upgrading: Evidence on the Impact of MERCOSUR on Argentinian Firms", American Economic Review 101, 304-340.

[10] Cai, Jing, and Ann Harrison. 2011. "The Value-Added Tax Reform Puzzle", NBER Working Paper 17532.

[11] Cassiman, Bruno, Elena Golovko, and Ester Martínez-Ros. 2010. "Innovation, Exports and Productivity", International Journal of Industrial Organization 28, 372376.

[12] Chandra, Piyush and Cheryl Long. 2013. "VAT Rebates and Export Performance in China: Firm-Level Evidence", Journal of Public Economics 103, 13-22. 
[13] Chen, Yuyu, Zongyan He, and Lei Zhang. 2011. "The Effect of Investment Tax Incentives: Evidence from China's Value-Added Tax Reform", Unpublished paper.

[14] Conley, Timothy, Christian Hansen and Peter Rossi. 2012. "Plausibly Exogenous", Review of Economics and Statistics, 94(1), 260-272.

[15] Criscuolo, Chiara, Jonathan E. Haskel, and Matthew J. Slaughter. 2010. "Global Engagement and the Innovation Activities of Firms", International Journal of Industrial Organization 28, 191-202..

[16] Damijan, Jože P., Črt Kostevc, and Sašo Polanec. 2008. "From Innovation to Exporting or Vice Versa?", LICOS discussion paper 20408.

[17] De Loecker, Jan, Pinelopi K. Goldberg, Amit K. Khandelwal, and Nina Pavcnik. 2014. "Prices, Markups and Trade Reform", Unpublished paper.

[18] Dougan, William and Lei Zhang. 2010. "Consumption Taxes, Income Taxes, and Saving: Evidence from OECD Countries." Unpublished manuscript.

[19] Iacovone, Leonardo and Beata S. Javorcik. 2012. "Getting Ready: Preparation for Exporting", mimeo, University of Oxford.

[20] Khandelwal, Amit K., P. Schott and S.J. Wei. 2013. "Trade Liberalization and Embedded Institutional Reform: Evidence from Chinese Exporters", The American Economic Review, 103(6), 2169-95.

[21] Levinsohn, James, and Amil Petrin. 2003. "Estimating Production Functions Using Inputs to Control for Unobservables," Review of Economic Studies 70(2), 317-341.

[22] Lileeva, Alla, and Daniel Trefler. 2010. "Improved Access to Foreign Markets Raises Plant-Level Productivity ... for Some Plants." Quarterly Journal of Economics 125(3), 1051-99.

[23] Manova, Kalina B. 2013. "Credit Constraints, Heterogeneous Firms, and International Trade", Review of Economic Studies 80, 711-744.

[24] Manova, Kalina B. and Zhihong Yu. 2014. "Firms and Credit Constraints along the Global Value Chain: Processing Trade in China", NBER Working Paper 18561.

[25] Mayer, Thierry, and Gianmarco Ottaviano. 2008. "The happy few: the internationalisation of European firms," Intereconomics: Review of European Economic Policy, 43(3), 135-148.

[26] Melitz, Marc. 2003. "The Impact of Trade on Intra-Industry Reallocations and Aggregate Industry Productivity." Econometrica 71(6): 1695-1725. 
[27] Metcalf, Gilbert E. 1995. "The Value-Added Tax: A Tax Whose Time Has Come?" Journal of Economic Perspectives 9(1), 121-40.

[28] Nunn N, Wantchekon L. 2011. "The Slave Trade and the Origins of Mistrust in Africa". American Economic Review 101(7), 3221-3252.

[29] Pavcnik, Nina. 2002. "Trade Liberalization, Exit, and Productivity Improvements: Evidence from Chilean Plants", Review of Economic Studies 69, 245-276.

[30] Redding, Stephen J. 2011. "Theories of Heterogeneous Firms and Trade", Annual Review of Economics 3, 77-105

[31] Song, Zheng and Guiying Wu. 2012. "A Structural Estimation on Capital Market Distortions in Chinese Manufacturing", mimeo, University of Chicago. 
Figure 1. Distribution of estimated coefficients with placebo year and cities of the VAT pilot reform

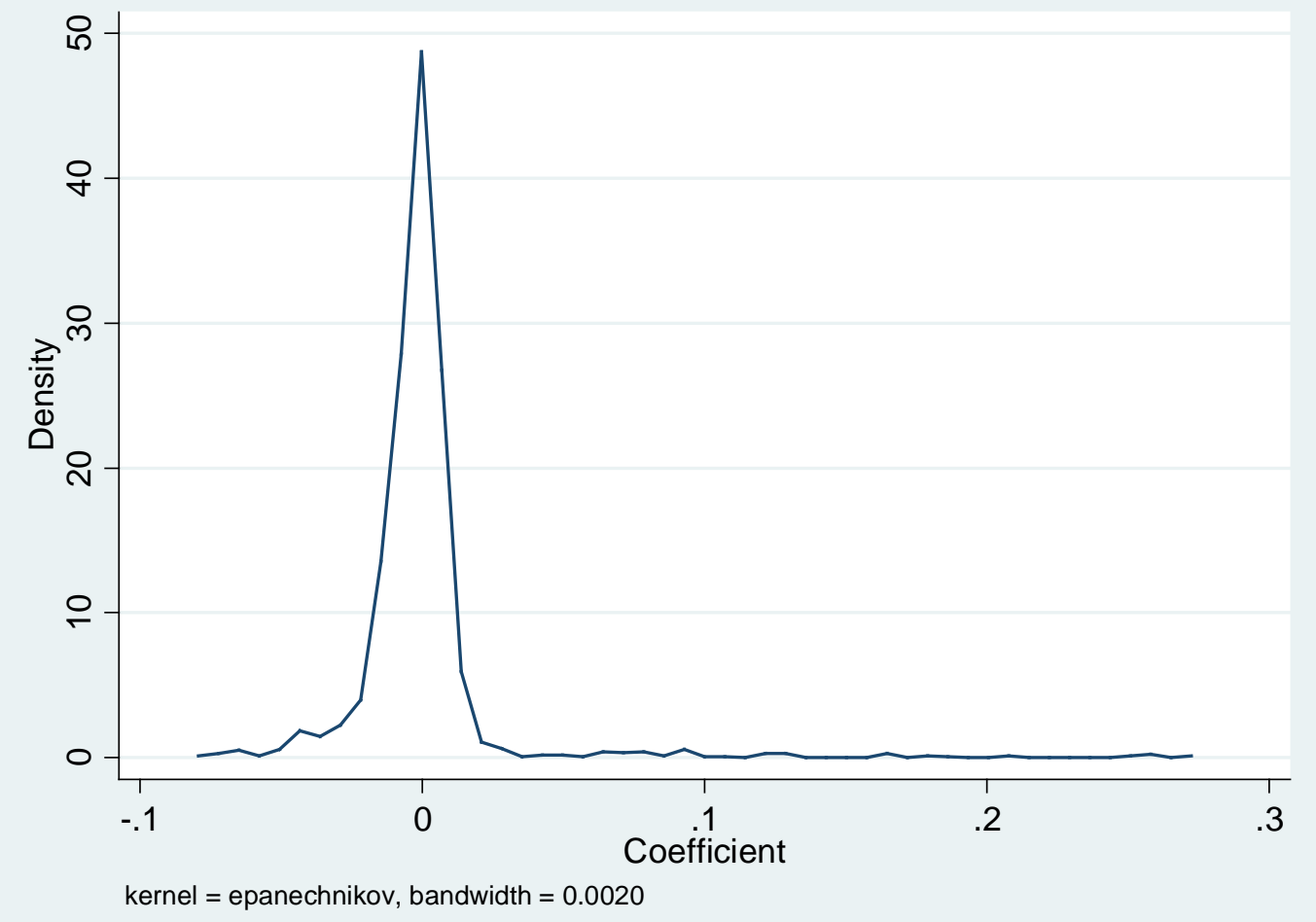


Table 1. Eligibility of manufacturing industries in the 2004 VAT pilot reform

Eligible Industries (industry code in bracket)

[13] agricultural and by-product

[14] food production

[15] beverage

[17] textile

[18] garments

[19] leather, furs, down and related products

[20] timber, bamboo, and straw products

[21] furniture

[22] paper making and paper products

[251] refined petroleum products

[253] nuclear fuel processing

[26] raw chemical material and chemical products

[27] medical and pharmaceutical products

[28] chemical fiber

[29] rubber

[30] plastic

[32] smelting and pressing of ferrous metals

[33] smelting and pressing of non-ferrous metals

[35] ordinary machinery

[36] special equipment

[371] railway transport equipment

[372] automobile

[375] ships and floating equipment

[376] aerospace and aeronautic equipment

[379] other transportation equipment

[39] electric machines and apparatuses

[40] computer and communication equipment

[41] instruments, cultural and office machinery

[42] crafts work and other manufactures

Ineligible Industries (industry code in bracket)

[16] tobacco

[23] printing and record medium reproduction

[24] cultural, education, sports article production

[252] coking

[31] non-metal mineral products

[34] metal products

[373] motorcycle

[374] bicycle

[378] transportation equipment repairing 
[43] waste recycling and processing

Source: Decision of the Ministry of Finance and the State Administration of Taxation on

Issues on the Expansion of Deduction of the Value-Added Taxation in the Northeastern

Provinces (September 14, 2004) 
Table 2a. Summary statistics

\begin{tabular}{|c|c|c|c|c|c|}
\hline & (1) & (2) & (3) & $(3)-(2)$ & Definition \\
\hline Variable & Whole & $\begin{array}{c}\text { NE } \\
\text { Cities }\end{array}$ & $\begin{array}{c}\text { non-NE } \\
\text { Cities }\end{array}$ & & \\
\hline Exporting status & $\begin{array}{r}0.3294 \\
(0.0005)\end{array}$ & $\begin{array}{r}0.2189 \\
(0.0020)\end{array}$ & $\begin{array}{r}0.3361 \\
(0.0006)\end{array}$ & $0.1172^{\star \star \star}$ & An indicator of exporters \\
\hline Export intensity & $\begin{array}{r}0.1979 \\
(0.0004)\end{array}$ & $\begin{array}{r}0.1226 \\
(0.0014)\end{array}$ & $\begin{array}{r}0.2024 \\
(0.0004)\end{array}$ & $0.0798^{\star \star \star}$ & Ratio of exports over total output \\
\hline In (1+Export value) & $\begin{array}{r}3.1799 \\
(0.0054)\end{array}$ & $\begin{array}{r}2.0876 \\
(0.0196)\end{array}$ & $\begin{array}{r}3.2460 \\
(0.0056)\end{array}$ & $1.1584^{\star \star \star}$ & Logarithm of (1+exports) \\
\hline In (1+Export markets) & $\begin{array}{r}0.4237 \\
(0.0011)\end{array}$ & $\begin{array}{r}0.2883 \\
(0.0037)\end{array}$ & $\begin{array}{r}0.4318 \\
(0.0012)\end{array}$ & $0.1435^{\star \star \star}$ & Logarithm of (1+no. of markets exported) \\
\hline In(1+Fixed investment) & $\begin{array}{r}6.4942 \\
(0.0027)\end{array}$ & $\begin{array}{r}6.4446 \\
(0.0125)\end{array}$ & $\begin{array}{r}6.4972 \\
(0.0027)\end{array}$ & $0.0526 * \star \star$ & Logarithm of (1+fixed investment) \\
\hline In Employment & $\begin{array}{r}4.9787 \\
(0.0013)\end{array}$ & $\begin{array}{r}4.9586 \\
(0.0059)\end{array}$ & $\begin{array}{r}4.9799 \\
(0.0013)\end{array}$ & $0.0213^{\star \star \star}$ & Logarithm of total employment \\
\hline In Wage & $\begin{array}{r}2.4203 \\
(0.0008)\end{array}$ & $\begin{array}{r}2.2672 \\
(0.0036)\end{array}$ & $\begin{array}{r}2.4295 \\
(0.0008)\end{array}$ & $0.1623^{\star \star *}$ & Logarithm of wage rate \\
\hline
\end{tabular}


Table 2b. Sectoral comparison of exporter shares

\begin{tabular}{|c|c|c|c|c|c|c|}
\hline \multirow[t]{2}{*}{ Industry } & \multicolumn{2}{|c|}{$\begin{array}{l}\text { NE Cities } \\
\text { (1) }\end{array}$} & \multicolumn{2}{|c|}{$\begin{array}{l}\text { non-NE Cities } \\
\text { (2) }\end{array}$} & \multicolumn{2}{|c|}{$\begin{array}{l}\text { Difference } \\
(2)-(1)\end{array}$} \\
\hline & Mean & Std. Err. & Mean & Std. Err. & Mean & Std. Err. \\
\hline [13] agricultural and by-product & 0.2259 & $(0.0061)$ & 0.1879 & $(0.0017)$ & $-0.0380^{\star \star \star}$ & $(0.0060)$ \\
\hline [14] food production & 0.1407 & $(0.0088)$ & 0.2559 & $(0.0030)$ & $0.1152^{\star \star \star}$ & $(0.0114)$ \\
\hline [15] beverage & 0.0431 & $(0.0053)$ & 0.1436 & $(0.0029)$ & $0.1005^{\star \star \star}$ & $(0.0093)$ \\
\hline [17] textile & 0.4604 & $(0.0112)$ & 0.4070 & $(0.0017)$ & $-0.0534^{\star \star \star}$ & $(0.0111)$ \\
\hline [18] garments & 0.7246 & $(0.0113)$ & 0.6554 & $(0.0022)$ & $-0.0692^{\star \star \star}$ & $(0.0122)$ \\
\hline [19] leather, furs, down and related products & 0.6186 & $(0.0267)$ & 0.6340 & $(0.0033)$ & 0.0154 & $(0.0266)$ \\
\hline [20] timber, bamboo, and straw products & 0.2259 & $(0.0125)$ & 0.2656 & $(0.0041)$ & $0.0397^{\star \star \star}$ & $(0.0138)$ \\
\hline [21] furniture & 0.4801 & $(0.0189)$ & 0.4710 & $(0.0050)$ & -0.0091 & $(0.0195)$ \\
\hline [22] paper making and paper products & 0.0762 & $(0.0076)$ & 0.1243 & $(0.0020)$ & $0.0481^{\star * \star}$ & $(0.0096)$ \\
\hline [25] petroleum processing & 0.1140 & $(0.0115)$ & 0.0801 & $(0.0048)$ & $-0.0339 * \star \star$ & $(0.0113)$ \\
\hline [26] raw chemical material and chemical products & 0.1633 & $(0.0061)$ & 0.2398 & $(0.0017)$ & $0.0765^{\star \star \star}$ & $(0.0072)$ \\
\hline [27] medical and pharmaceutical products & 0.1167 & $(0.0083)$ & 0.2789 & $(0.0035)$ & $0.1622^{\star \star \star}$ & $(0.0118)$ \\
\hline [28] chemical fiber & 0.1793 & $(0.0320)$ & 0.2111 & $(0.0059)$ & 0.0318 & $(0.0343)$ \\
\hline [29] rubber & 0.3168 & $(0.0180)$ & 0.3616 & $(0.0045)$ & $0.0448^{* *}$ & $(0.0191)$ \\
\hline [30] plastic & 0.1506 & $(0.0080)$ & 0.3387 & $(0.0023)$ & $0.1881^{\star \star \star}$ & $(0.0108)$ \\
\hline [32] smelting and pressing of ferrous metals & 0.1704 & $(0.0088)$ & 0.1156 & $(0.0023)$ & $-0.0548^{\star \star \star}$ & $(0.0079)$ \\
\hline [33] smelting and pressing of non-ferrous metals & 0.1722 & $(0.0124)$ & 0.1805 & $(0.0031)$ & 0.0083 & $(0.0130)$ \\
\hline [35] ordinary machinery & 0.2080 & $(0.0056)$ & 0.2852 & $(0.0018)$ & $0.0772^{\star * *}$ & $(0.0064)$ \\
\hline [36] special equipment & 0.1478 & $(0.0068)$ & 0.2591 & $(0.0023)$ & $0.1113^{\star \star \star}$ & $(0.0086)$ \\
\hline [37] transport equipment & 0.1349 & $(0.0058)$ & 0.2280 & $(0.0023)$ & $0.0931^{* * *}$ & $(0.0074)$ \\
\hline [39] electric machines and apparatuses & 0.1475 & $(0.0066)$ & 0.3432 & $(0.0021)$ & $0.1957^{\star \star \star}$ & $(0.0090)$ \\
\hline [40] computer and communication equipment & 0.4190 & $(0.0176)$ & 0.5488 & $(0.0031)$ & $0.1299 * \star \star$ & $(0.0180)$ \\
\hline [41] instruments, cultural and office machinery & 0.1838 & $(0.0149)$ & 0.4758 & $(0.0042)$ & 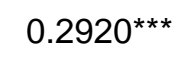 & $(0.0194)$ \\
\hline [42] crafts work and other manufactures & 0.6907 & $(0.0239)$ & 0.7173 & $(0.0033)$ & 0.0266 & $(0.0235)$ \\
\hline
\end{tabular}


Table 3. Main results

\begin{tabular}{|c|c|c|c|c|}
\hline & (1) & $(2)$ & (3) & (4) \\
\hline Panel A, Second-Stage: Dependent Variable & $\mathrm{EXP}_{\mathrm{t}}$ & & $\mathrm{EXP}_{\mathrm{t}}$ & \\
\hline \multirow{2}{*}{$\mathrm{INV}_{\mathrm{t}-1}$} & $0.1332^{\star * *}$ & $0.1181^{\star * \star}$ & $0.1730^{* * *}$ & * 0.1690 *** \\
\hline & $(0.0236)$ & $(0.0208)$ & $(0.0287)$ & $(0.0305)$ \\
\hline \multicolumn{5}{|l|}{ Firm-Level Controls } \\
\hline \multirow[t]{2}{*}{ Exporting Status $\mathrm{S}_{\mathrm{t}-1}$} & $0.5752^{\star \star \star}$ & $0.5779 * \star \star$ & $0.5699 * \star \star$ & * $0.5728^{\star \star \star}$ \\
\hline & $(0.0077)$ & $(0.0078)$ & $(0.0089)$ & $(0.0075)$ \\
\hline \multirow[t]{2}{*}{ Exporting Status $\mathrm{t}_{-2}$} & $0.2319^{\star \star \star}$ & $0.2311^{\star \star \star}$ & $0.2346^{\star \star \star}$ & * $0.2358^{\star \star \star}$ \\
\hline & $(0.0076)$ & $(0.0093)$ & $(0.0082)$ & $(0.0072)$ \\
\hline \multirow[t]{2}{*}{ Ln Employment $\mathrm{t}_{\mathrm{t}-1}$} & $-0.1165^{\star \star \star}$ & $-0.1010^{\star \star \star}$ & $\star-0.1596^{\star \star \star}$ & $*-0.1561^{* \star *}$ \\
\hline & $(0.0244)$ & $(0.0210)$ & $(0.0298)$ & $(0.0317)$ \\
\hline \multirow[t]{2}{*}{ Ln Wage $_{t-1}$} & $-0.1058^{\star \star \star}$ & $-0.0919 * \star \star$ & $\star-0.1411^{\star \star \star}$ & $*-0.1348^{\star \star *}$ \\
\hline & $(0.0216)$ & $(0.0203)$ & $(0.0265)$ & $(0.0260)$ \\
\hline \multirow[t]{2}{*}{ MFA*Post05 } & $-0.0119 * \star \star$ & $-0.0128^{\star \star \star}$ & $\star-0.0128^{\star \star \star}$ & $\star-0.0141^{\star \star \star}$ \\
\hline & $(0.0040)$ & $(0.0032)$ & $(0.0030)$ & $(0.0032)$ \\
\hline \multirow[t]{2}{*}{ State Share $_{\mathrm{t}}$} & & & $0.0726^{\star \star \star}$ & \\
\hline & & & $(0.0159)$ & \\
\hline \multirow[t]{2}{*}{$\mathrm{SOE}_{\mathrm{t}}$} & & & & $0.0829 * \star \star$ \\
\hline & & & & $(0.0174)$ \\
\hline \multirow[t]{2}{*}{ Foreign-invested firms $\mathrm{s}_{\mathrm{t}}$} & & & & -0.0050 \\
\hline & & & & $(0.0096)$ \\
\hline \multirow[t]{2}{*}{ HMT-invested firms $_{t}$} & & & & -0.0148 \\
\hline & & & & $(0.0149)$ \\
\hline Year Fixed Effect & $x$ & $x$ & $x$ & $x$ \\
\hline Industry Fixed Effect & $x$ & $x$ & $x$ & $x$ \\
\hline City Fixed Effect & $x$ & $x$ & $x$ & $x$ \\
\hline
\end{tabular}

Panel B, First-Stage: Dependent Variable is INV $\mathrm{t}_{\mathrm{t}-1}$

$\begin{array}{llllll}\text { VAT }_{\mathrm{t}-1} & 0.1791^{* *} & 0.1791^{* *} & 0.1301^{*} & 0.1349^{*} \\ & (0.0882) & (0.0882) & (0.0782) & (0.0811)\end{array}$

Firm-Level Controls

Year Fixed Effect

Industry Fixed Effect

$\begin{array}{llll}x & x & x\end{array}$

City Fixed Effect

$x \quad x \quad x \quad x$

$x \quad x \quad x \quad x$

\begin{tabular}{lllll}
\hline Observations & 722,015 & 722,015 & 718,485 & 722,015 \\
\hline
\end{tabular}

Robust standard errors clustered at the city in parentheses. ${ }^{* *} p<0.01,{ }^{* *} p<0.05$, * $p<0.10$ 
Table 4. Robustness checks

\begin{tabular}{|c|c|c|c|c|c|c|c|}
\hline $\begin{array}{l}\text { Specification/Sample } \\
\text { Dependent Variable }\end{array}$ & $\begin{array}{l}\text { (1) } \\
\text { S.E. at the } \\
\text { Province-level }\end{array}$ & $\begin{array}{l}\text { (2) } \\
\begin{array}{c}\text { Single-industry } \\
\text { firms }\end{array}\end{array}$ & $\begin{array}{l}\text { (3) } \\
\text { Multi-industry } \\
\text { firms } \\
\widetilde{\mathrm{EXP}_{\mathrm{t}}}\end{array}$ & $\begin{array}{l}\text { (4) } \\
\text { Surviving } \\
\text { firms }\end{array}$ & $\begin{array}{c}(5) \\
\text { Use K/L to } \\
\text { measure } \\
\text { investment }\end{array}$ & SOES & Non-SOEs \\
\hline $\mathrm{INV}_{\mathrm{t}-1}$ & $\begin{array}{l}0.1730 * \\
(0.0972)\end{array}$ & $\begin{array}{l}0.2098^{\star \star *} \\
(0.0366)\end{array}$ & $\begin{array}{c}0.1270 \\
(0.0945)\end{array}$ & $\begin{array}{l}0.2096 * \star * \\
(0.0551)\end{array}$ & & $\begin{array}{c}0.0159 \\
(0.0510)\end{array}$ & $\begin{array}{l}0.3096 * \star \star \\
(0.0478)\end{array}$ \\
\hline Capital-Labor Ratio $_{\mathrm{t}-1}$ & & & & & $\begin{array}{c}0.1375^{\star \star *} \\
(0.0244)\end{array}$ & & \\
\hline Firm-Level Controls & $x$ & $x$ & $x$ & $x$ & $x$ & $x$ & $x$ \\
\hline Year Fixed Effect & $x$ & $x$ & $x$ & $x$ & $x$ & $x$ & $x$ \\
\hline Industry Fixed Effect & $\mathrm{X}$ & $x$ & $\mathrm{X}$ & $X$ & $x$ & $\mathrm{X}$ & $x$ \\
\hline City Fixed Effect & $X$ & $X$ & $X$ & $X$ & $X$ & $X$ & $X$ \\
\hline Observations & 718,485 & 645,769 & 72,716 & 386,292 & 717,313 & 82,769 & 635,716 \\
\hline
\end{tabular}

Robust standard errors clustered at the city in parentheses (except column 1). ${ }^{* \star} p<0.01,{ }^{*} p<0.10$ 
Table 5. Productivity enhancement

\begin{tabular}{|c|c|c|c|c|c|c|}
\hline & (1) & (2) & (3) & (4) & (5) & (6) \\
\hline Sample & \multicolumn{2}{|c|}{ Full Sample } & \multicolumn{2}{|c|}{ SOES } & \multicolumn{2}{|c|}{ Non-SOEs } \\
\hline Dependent Variable & $\mathrm{TFP}_{\mathrm{t}}$ & $\widetilde{\mathrm{EXP}_{\mathrm{t}}}$ & $\mathrm{TFP}_{\mathrm{t}}$ & $\mathrm{EXP}_{t}$ & $\mathrm{TFP}_{\mathrm{t}}$ & $\widetilde{E X P}_{t}$ \\
\hline $\mathrm{INV}_{\mathrm{t}-1}$ & $\begin{array}{c}1.6278^{\star * *} \\
(0.4236)\end{array}$ & & $\begin{array}{c}0.6281^{*} \\
(0.3393)\end{array}$ & & $\begin{array}{c}2.5690^{\star \star \star} \\
(0.8028)\end{array}$ & \\
\hline $\mathrm{TFP}_{\mathrm{t}}$ & & $\begin{array}{c}0.0941^{\star \star \star} \\
(0.0158)\end{array}$ & & $\begin{array}{c}0.0083 \\
(0.0539)\end{array}$ & & $\begin{array}{c}0.1138^{\star * *} \\
(0.0154)\end{array}$ \\
\hline Firm-level Controls & $x$ & $x$ & $x$ & $x$ & $x$ & $x$ \\
\hline Year Fixed Effect & $x$ & $\mathrm{X}$ & $x$ & $\mathrm{X}$ & $x$ & $x$ \\
\hline Industry Fixed Effect & $x$ & $x$ & $x$ & $x$ & $x$ & $x$ \\
\hline City Fixed Effect & $x$ & $x$ & $x$ & $x$ & $x$ & $x$ \\
\hline Observations & 707,242 & 707,930 & 79,132 & 79,453 & 628,110 & 628,477 \\
\hline
\end{tabular}

Robust standard errors clustered at the city in parentheses. *** $p<0.01,{ }^{*} p<0.10$ 
Table 6. Financial constraints and pass-through

\begin{tabular}{|c|c|c|c|c|}
\hline $\begin{array}{l}\text { Sample } \\
\text { Dependent Variable }\end{array}$ & $\begin{array}{c}(1) \\
\text { High Financial } \\
\text { Dependence Industries }\end{array}$ & $\begin{array}{c}(2) \\
\text { Low Financial } \\
\text { Dependence Industries } \\
\widetilde{\mathrm{EXP}}_{\mathrm{t}}\end{array}$ & $\begin{array}{c}\text { (3) } \\
\text { High } \mathrm{HHI} \\
\text { Industries }\end{array}$ & $\begin{array}{c}\text { (4) } \\
\text { Low HHI } \\
\text { Industries }\end{array}$ \\
\hline$I_{N} V_{t-1}$ & $\begin{array}{l}0.2417^{\star \star \star} \\
(0.0411)\end{array}$ & $\begin{array}{l}0.1133^{\star \star \star} \\
(0.0230)\end{array}$ & $\begin{array}{l}0.1391^{\star *} \\
(0.0554)\end{array}$ & $\begin{array}{l}0.1844^{\star \star \star} \\
(0.0356)\end{array}$ \\
\hline Firm-level Controls & $x$ & $x$ & $x$ & $x$ \\
\hline Year Fixed Effect & $\mathrm{X}$ & $x$ & $x$ & $x$ \\
\hline Industry Fixed Effect & $x$ & $x$ & $x$ & $x$ \\
\hline City Fixed Effect & $x$ & $x$ & $x$ & $x$ \\
\hline Observations & 414,730 & 303,755 & 107,105 & 611,380 \\
\hline
\end{tabular}

Robust standard errors clustered at the city in parentheses. ${ }^{* \star *} p<0.01,{ }^{\star *} p<0.05$ 
Appendix Figure 1. Correlation between external financial dependence and SOE share across 4-digit industries

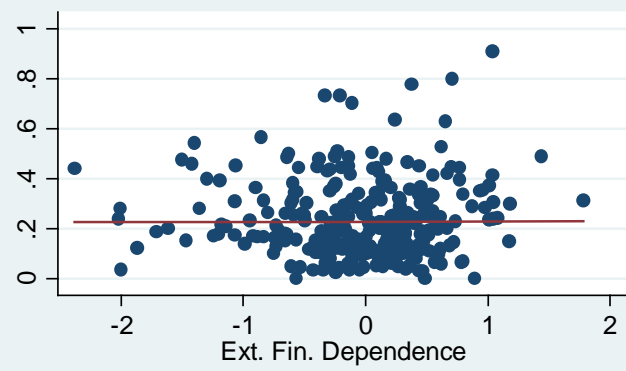

- SOE Share_number $\quad$ Fitted values

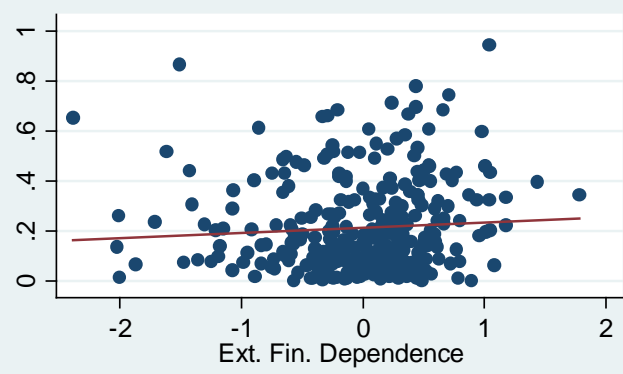

- SOE Share_sale — Fitted values

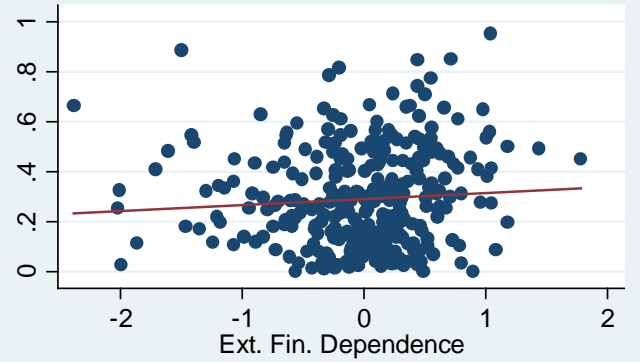

- SOE Share_labor — Fitted values

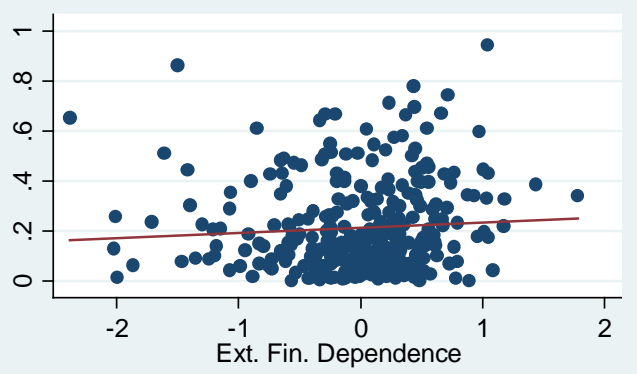

- SOE Share_output Fitted values 
Appendix Figure 2. Correlation between $\mathrm{HHI}$ and SOE share across 4-digit industries
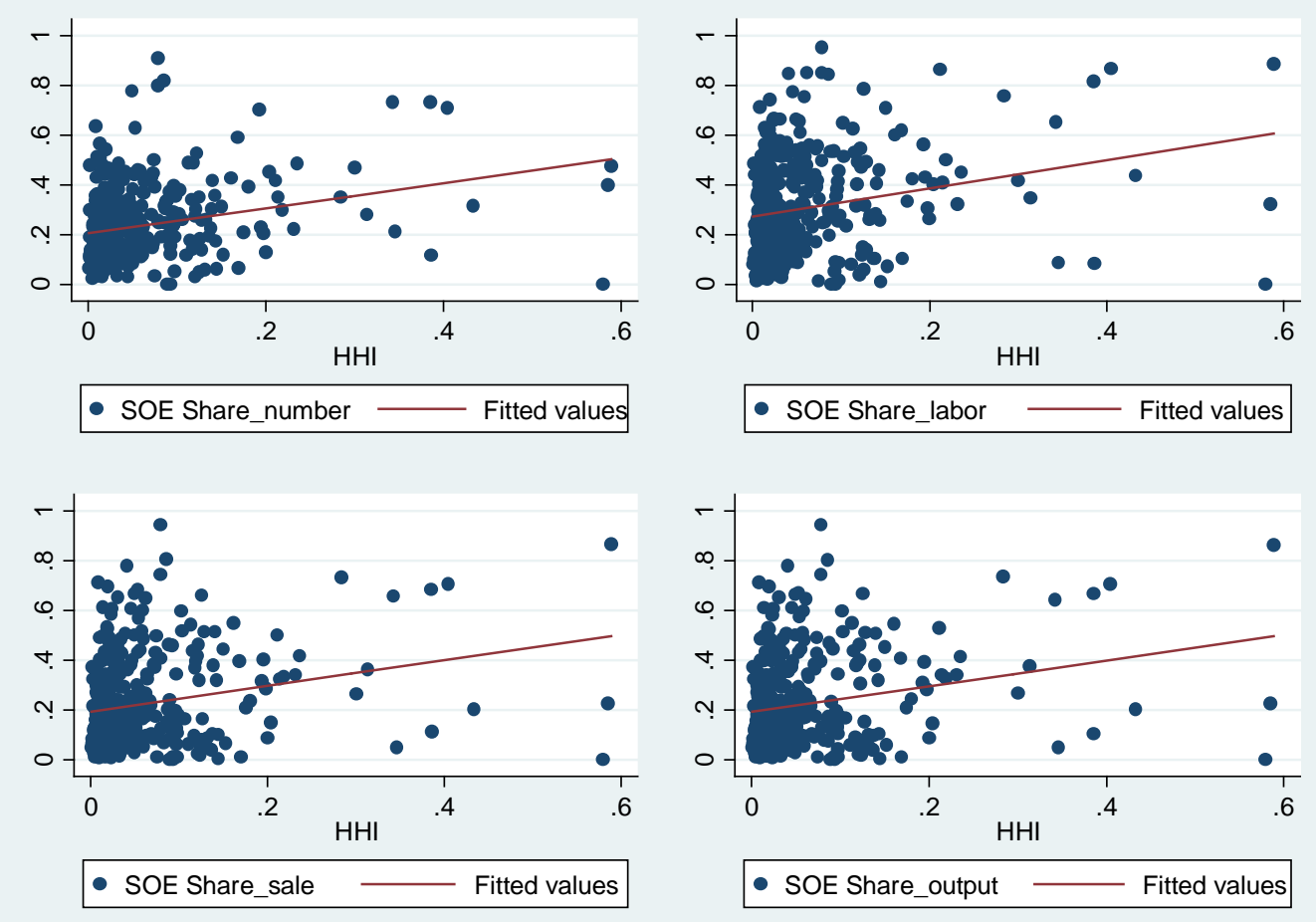
Appedix Table 1. Additional results

\begin{tabular}{|c|c|c|c|c|c|c|c|}
\hline $\begin{array}{l}\text { Specification/Sample } \\
\text { Dependent Variable }\end{array}$ & $\begin{array}{c}\text { (1) } \\
\text { 3-digit } \\
\text { industry FE } \\
\text { E }\end{array}$ & $\begin{array}{l}\text { (2) } \\
\text { 4-digit } \\
\text { industry FE } \\
\mathrm{P}_{\mathrm{t}}\end{array}$ & Exports $_{t}$ & Export Intensity $_{t}$ & Export Markets $_{\mathrm{t}}$ & $\begin{array}{l}\text { Control for } \\
\text { Debt }\end{array}$ & $\begin{array}{l}(7) \\
\text { Excluding Firms in } \\
\text { Both Eligible and } \\
\text { Ineligible } \\
\text { Industries } \\
\widetilde{E X P}_{t}\end{array}$ \\
\hline $\mathrm{INV}_{\mathrm{t}-1}$ & $\begin{array}{c}0.1830 * \star * \\
(0.0322)\end{array}$ & $\begin{array}{c}0.1888 * \star * \\
(0.0371)\end{array}$ & $\begin{array}{c}1.8478^{\star \star \star} \\
(0.4285)\end{array}$ & $\begin{array}{c}0.0109 \\
(0.0446)\end{array}$ & $\begin{array}{c}0.1239 \\
(0.0877)\end{array}$ & $\begin{array}{c}0.1549 * * \star \\
(0.0259)\end{array}$ & $\begin{array}{c}0.1737^{\star \star \star} \\
(0.0288)\end{array}$ \\
\hline Ln Total Debt $t_{t}$ & & & & & & $\begin{array}{c}-0.0397^{\star \star \star} \\
(0.0071)\end{array}$ & \\
\hline Firm-Level Controls & $x$ & $x$ & $x$ & $x$ & $x$ & $x$ & $x$ \\
\hline Year Fixed Effect & $x$ & $x$ & $x$ & $x$ & $x$ & $x$ & $x$ \\
\hline Industry Fixed Effect & $x$ & $x$ & $x$ & $x$ & $x$ & $x$ & $x$ \\
\hline City Fixed Effect & $x$ & $x$ & $x$ & $x$ & $x$ & $x$ & $\mathrm{X}$ \\
\hline Observations & 718,485 & 718,485 & 718,485 & 718,485 & 564,376 & 717,531 & 713,876 \\
\hline
\end{tabular}

Robust standard errors clustered at the city in parentheses. ${ }^{\star \star \star} p<0.01$. 
Appendix Table 2. Heterogeneous effects of the VAT pilot reform

\begin{tabular}{|c|c|c|}
\hline VARIABLES & $\begin{array}{l}(1) \\
\text { INVt }\end{array}$ & $\begin{array}{l}(2) \\
\text { EXPt }\end{array}$ \\
\hline VATt-1 & $\begin{array}{l}0.1836 * * * \\
(0.0608)\end{array}$ & $\begin{array}{l}0.0289 * \star \star \\
(0.0046)\end{array}$ \\
\hline $\begin{array}{l}\text { VATt-1 *Indicator of Initial non-Exporters } \\
\text { with High TFP }\end{array}$ & $\begin{array}{l}-0.1465^{\star *} \\
(0.0570)\end{array}$ & $\begin{array}{l}-0.0018 \\
(0.0051)\end{array}$ \\
\hline VATt-1 * Indicator of Initial Exporters & $\begin{array}{l}-0.1184 \\
(0.1361)\end{array}$ & $\begin{array}{c}-0.0856^{\star * *} \\
(0.0172)\end{array}$ \\
\hline $\begin{array}{l}\text { Firm-level Controls } \\
\text { Year Fixed Effect } \\
\text { Industry Fixed Effect } \\
\text { City Fixed Effect }\end{array}$ & $\begin{array}{l}x \\
X \\
X \\
X\end{array}$ & $\begin{array}{l}X \\
X \\
X \\
X\end{array}$ \\
\hline $\begin{array}{l}\text { Implied effects } \\
\text { Initial non-Exporters with Low TFP } \\
\text { Initial non-Exporters with High TFP } \\
\text { Initial Exporters }\end{array}$ & $\begin{array}{c}0.1836^{\star \star *} \\
0.0371 \\
0.0652 \\
\end{array}$ & $\begin{array}{c}0.0289^{\star \star *} \\
0.0271^{\star \star *} \\
-0.0567^{\star \star \star}\end{array}$ \\
\hline $\begin{array}{l}\text { Observations } \\
\text { R-squared }\end{array}$ & $\begin{array}{l}517,729 \\
0.4045\end{array}$ & $\begin{array}{l}517,729 \\
0.7685\end{array}$ \\
\hline
\end{tabular}

